\title{
Utilization of Rice Husks into Biochar and Nanosilica: For Clean Energy, Soil Fertility and Green Nanotechnology
}

\author{
Marilou M. Sarong ${ }^{1,4^{*}}$, Ricardo F. Orge ${ }^{2}$, Paul Jhon G. Eugenio ${ }^{3}$, Juvy J. Monserate ${ }^{3,4}$ \\ ${ }^{1}$ Department of Soil Science, Central Luzon State University, Science City of Muñoz, Nueva Ecija, Philippines \\ ${ }^{2}$ Rice Engineering and Mechanization Division (REMD), Philippine Rice Research Institute - Central Experimental Station, \\ Science City of Muñoz, Nueva Ecija, Philippines \\ ${ }^{3}$ Department of Chemistry, Central Luzon State University, Science City of Muñoz, Nueva Ecija, Philippines \\ ${ }^{4}$ Nanotechnology R \& D Facility, Central Luzon State University, Science City of Munoz, Nueva Ecija, Philippines
}

Corresponding Author Email: malousarss@gmail.com

https://doi.org/10.18280/ijdne.150113

Received: 31 May 2019

Accepted: 18 February 2020

\section{Keywords:}

rice husks biochar, nanochar, green nanotechnology, $\mathrm{SiO}_{2}$

\begin{abstract}
Rice husks are often dumped and burned in the field that emits greenhouse gases. Through green nanotechnology, developing these materials into diverse applications will not only create an avenue for new ideas and innovations but also beneficial to the environment. Thus, this study aimed to utilize rice husks in an eco-friendly way. Rice husks were converted into rice husk biochar (RHB) through continuous-type rice husk pyrolizer (CtRHP) which produces two important products: heat energy and biochar. High grade RHB was used as an amendment for degraded acid upland soil (Annam series) grown with corn. Plant height and biomass, and total $\mathrm{N}$ uptake, increased linearly with increasing rates of RHB levels. A linear trend of the effects of $\mathrm{RHB}$ on soil $\mathrm{pH}$ (water), and total $\mathrm{N}$ with the increasing $\mathrm{RHB}$ rates while soil $\mathrm{pH}$ and $\mathrm{OC}$ had a quadratic trend. The produced RHB were further derivatized into nanosilica $(\mathrm{nSi})$. Characterization of $\mathrm{nSi}$ through $\mathrm{SEM}$ micrographs showed a cloudy-like structure with various particle sizes ranging from 5 to $20 \mathrm{~nm}$, while XRD analysis revealed that the synthesized $\mathrm{nSi}$ is amorphous. Converting RHB into $\mathrm{nSi}$ will have various industrial applications such as catalysts, electronic and thin film substrates, and humidity sensors.
\end{abstract}

\section{INTRODUCTION}

Rice is the staple food for more than half of the world's population. In the processing of rice through milling, it produces some agricultural by-products like rice straw and rice husk [1]. Husk is the outermost layer of an agricultural product which is commonly treated as waste and discarded. According to Sarong and Orge [2], it is estimated that Philippines produces $3.2 \mathrm{M} \mathrm{mt}$ of rice hull waste yearly. It is reported that a combustion of 1 ton of rice husk in the field causes about $0.15 \mathrm{~kg}$ of $\mathrm{CO}_{2}$ is emitted to the atmosphere while $0.09 \mathrm{~kg}$ of methane gas is produced when rice hulls are left on the ground and naturally decomposed [3]. Due to the increasing number of this biomass, the scientific community are finding ways to convert these materials into valuable products and this has resulted in some new products such as biochar and nanosilica.

Biochar is the solid carbon-rich product obtained when biomass is heated at high temperatures $\left(350-700^{\circ} \mathrm{C}\right)$ under limited supply of oxygen in a process called pyrolysis [4]. There is an increasing evidence that application of charred materials can improved soil fertility and productivity in marginal tropical soils [5-7]. Biochar can be applied for both agricultural and environmental gains. In industrialized country, biochar is often produced by highly sophisticated and expensive machines. Continuous-type rice husk pyrolizer (CtRHP) is a locally design pyrolizer machine suited to
Philippines conditions with various applications - energy and soil amendment [8]. Compared to the existing open-type rice hull carbonizer where workers are exposed to heat and smoke, CtRHP produces almost smokeless emission with high RHB recovery rate and clean energy for other farm activities such as cooking, pasteurizing mushroom fruiting bags, pumping of irrigation water and heating poultry houses [9].

Rice husk contains high, 60-90\%, silica content [10], which could be converted into nanoparticles. Converting rice husk into biochar and nanosilica through green nanotechnology is a novel idea to utilize this waste material. Green nanotechnology has been described as the development of clean technologies, "to minimize potential environmental and human health risks associated with the manufacture and use of nanotechnology products, and to encourage replacement of existing products with new nanoproducts that are more environmentally friendly throughout their lifecycle. Green nanotechnology is a branch of green technology linking the concepts of green chemistry and green engineering, where the word "green" refers to the use of plant products [11] as in this case, rice husks. Researchers and scientist from different fields draw interests in green nanotechnology as a novel approach and state-of-theart science [12] with diverse applications to industry, agriculture and environment. The aim of this study is to utilize rice husk in an eco-friendly way: Clean energy and green nanotechnology. 


\section{METHODS}

\subsection{Concept of the study}

This study was conceptualized to explore alternatives in the use of rice husks, a common agricultural waste in Philippines, that is, for biochar production and further converting it into novel nanomaterial (nanosilica) for various agricultural usage.

Moreover, this study may be beneficial to the following:

Farmers' perspective. This research may serve as technology solution to farmers experiencing energy shortage in the farm. The cogeneration of biochar and heat would create a more sustainable farming practice since they fit in various activities within the farm.

Social and Ecological perspective. Aside from being a carbon sink (climate change mitigation), biochar helps improve soil conditions and fertility, which would translate into reduced use of commercial fertilizers while maintaining higher crop yields, and ultimately sustained higher income of the farmers.

Political perspectives. Green nanotechnology as new emerging technology will help in the formulation of policies best suited in Philippine conditions.

\subsection{Pyrolizer used in the study}

Figure 1 shows the PhilRice continuous-type rice hull pyrolizer (CtRHP) used in the study. According to Orge [9], CtRHP is made of $2 \mathrm{~mm}$ thick BI metal sheets with the dimension of $1.5 \mathrm{~m} \times 0.8 \mathrm{~m} \times 0.8 \mathrm{~m}$. The pyrolizer has a fully enclosed hopper to make it able to operate during windy conditions and produce high grade biochar. The hopper houses the inverted V-partition (made of the same $2 \mathrm{~mm}$ thick metal sheet used for the sidings) which forms an empty space once it is filled with rice hull. This empty space serves as the combustion chamber where combustion takes place as the ambient air mixes with the pyrolytic gases and those that are products of incomplete combustion. It is also where the material to be carbonized is initially ignited during the start of the operation. The inverted $\mathrm{V}$ partition is designed to be easily detachable to facilitate repair or replacement since it is the one that has the greatest chance of failure being the one exposed to extreme heat. Also the air inlet where the ambient air enters is detachable to facilitate during start up operation or when re- igniting the combustion while already in operation.

To start the operation, small amount of kerosene is sprinkled into the combustion chamber and then ignited. Once the flame has become vigorous and stabilized, the air inlet is put in place. The heat generated at the combustion chamber carbonizes the rice hulls in the immediate vicinity. Pyrolysis and partial combustion takes place and progresses radially. Because of the suction effect of the chimney, the pyrolytic gases and those generated due to partial combustion (most of which are combustible) are drawn into the combustion chamber where they get combusted as the ambient air, coming in from the air inlet holes mixes with them, thus smokeless emission are usually observed at chimney.

The opening at the bottom allows harvesting of the charcoal once the carbonization zone has already reached the bottom part of the machine. The carbonizer can accommodate 6 sacks $\sim(60 \mathrm{kgs})$ of rice hull with an average capacity of $24.2 \mathrm{~kg} / \mathrm{hr}$ [13]. It is mainly designed for rice husk carbonization but is also able to carbonized rice straw, coconut husks and wood which are readily available in most farms. Figure 2 shows a sample attachment in CtRHP.

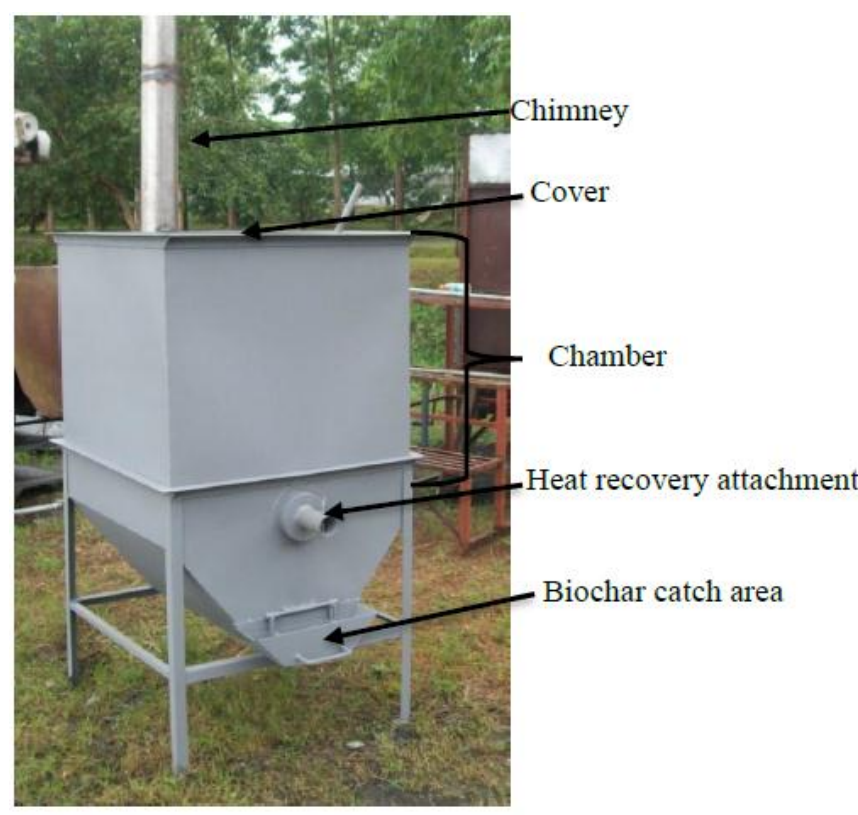

Figure 1. The CtRH pyrolyzer [9]

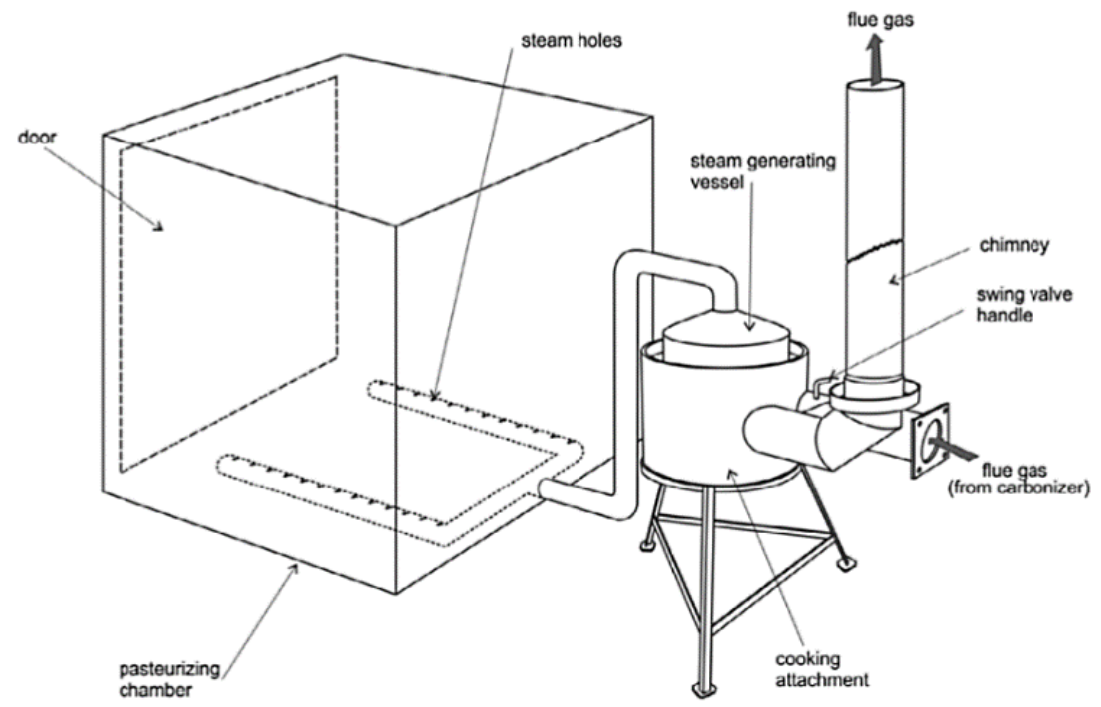

Figure 2. Sample attachment for CtRHP (for pasteurizing mushroom substrate) 


\subsection{RHB for improving soil fertility}

\subsubsection{Soil type and soil analyses}

Bulk samples from 0-20 cm alluvial Acidic sandy loam soil was collected Brgy. Pinagpanaan, Talavera, Nueva Ecija, Philippines. The experiment was carried out with the following particle size distribution: $71.22 \%$ sand, $20.41 \%$ silt, and $8.37 \%$ clay; had a $\mathrm{pH}_{\mathrm{KCl}}$ of $4.93,0.64 \%$ organic $\mathrm{C}, 0.16 \%$ total $\mathrm{N}, 1.53 \mathrm{mg} \mathrm{kg}-1$ extractable $\mathrm{P}, 2.88 \mathrm{cmol}^{+} \mathrm{kg}^{-1}$ soil exchangeable $\mathrm{Al}, 3.08 \mathrm{cmol}^{+} \mathrm{kg}^{-1}$ soil exchangeable acidity, $0.25 \mathrm{cmol}^{+} \mathrm{kg}-1$ soil exchangeable $\mathrm{K}, 3.57 \mathrm{cmol}^{+} \mathrm{kg}^{-1}$ soil exchangeable $\mathrm{Ca}, 1.38 \mathrm{cmol}^{+} \mathrm{kg}^{-1}$ soil exchangeable $\mathrm{Mg}$, and $0.25 \mathrm{cmol}^{+} \mathrm{kg}^{-1}$ soil exchangeable $\mathrm{Na}$ (Table 1).

Table 1. Initial properties of the soil

\begin{tabular}{|c|c|c|}
\hline Property & Method & Value \\
\hline $\begin{array}{l}\mathrm{pH}(1: 2.5 \text { soil to } 0.01 \mathrm{M} \\
\left.\mathrm{KCl}_{2}\right)\end{array}$ & Potentiometric [14] & 4.93 \\
\hline $\begin{array}{c}\text { Exchangeable } \mathrm{Al}\left(\mathrm{cmol}^{+} \mathrm{kg}^{-}\right. \\
\left.{ }^{-} \text {soil }\right)\end{array}$ & Potassium Chloride [15] & 2.88 \\
\hline $\begin{array}{l}\text { Exchangeable Acidity } \\
\quad\left(\mathrm{cmol}^{+} \mathrm{kg}^{-1} \text { soil }\right)\end{array}$ & Potassium Chloride [15] & 3.08 \\
\hline Organic C (\%) & $\begin{array}{c}\text { Modified Walkley Black } \\
{[14]}\end{array}$ & 0.64 \\
\hline Total N (\%) & $\begin{array}{l}\text { Modified micro- } \\
\text { Kjeldahl [16] }\end{array}$ & 0.16 \\
\hline Extractable P (mg kg-1 soil) & Olsen extractant [14] & 1.53 \\
\hline $\begin{array}{l}\text { Exchangeable bases }\left(\mathrm{cmol}^{+}\right. \\
\left.\mathrm{kg}^{-1} \text { soil }\right)\end{array}$ & $\begin{array}{l}\text { Ammonium acetate } \\
\text { method [17] }\end{array}$ & \\
\hline $\mathrm{K}$ & & 0.25 \\
\hline $\mathrm{Ca}$ & & 3.57 \\
\hline $\mathrm{Mg}$ & & 1.38 \\
\hline $\mathrm{Na}$ & & 0.25 \\
\hline $\begin{array}{c}\text { CEC Effective } \\
\left(\mathrm{cmol}^{+} \mathrm{kg}^{-1} \text { soil }\right)\end{array}$ & $\begin{array}{l}\text { Ammonium acetate } \\
\text { method [17] }\end{array}$ & 8.43 \\
\hline
\end{tabular}

\subsubsection{Application of inorganic fertilizers}

Half of the recommended rate per hectare were applied to each pot. Blanket application of $40 \mathrm{mg} \mathrm{N}, 60 \mathrm{mg} \mathrm{P}_{2} \mathrm{O}_{5}$ and 60 $\mathrm{mg} \mathrm{K}_{2} \mathrm{O} \mathrm{kg}^{-1}$ soil was done using urea, solophos and muriate of potash, respectively. Urea and muriate of potash were applied as aqueous solution while solophos was applied as granules five days after the seedlings had emerged.

\subsubsection{Plant management and statistical analyses}

Ten kg of soil (air-dired and sieved through 2-mm) was used in each pot. All replications were planted 10 days after RHB application (maintained at $\sim 80 \%$ Field Capacity). Eight corn (var. saccharata) seed were sown in each treatment pot. One week after sowing, thinning was done leaving two plants per pot. The plants were harvested 49 days after planting by cutting the shoots close to the soil surface. The soils adhering to the roots were removed carefully. The harvested shoots and roots were washed with tap water and rinsed with distilled water. After thorough washing, the plant samples were blot dried using paper towel and placed separately in paper bags. These were placed separately in a forced draft oven set at $70^{\circ} \mathrm{C}$ until constant weight was attained. The oven dried shoots and roots of two plants per pot were weighed and ground separately to particle size less than $1.0 \mathrm{~mm}$ using the stainless
Wiley Mill grinder. Ground shoots and roots of two plants per pot were combined and composite sample was prepared by combining $1 \mathrm{~g}$ from the roots and $2 \mathrm{~g}$ from the shoots The composite samples were analyzed for $\mathrm{N}$ and $\mathrm{P}$ uptake. Statistical Tool for Agricultural Research (STAR Ver. 2.0) was used to compare treatment means.

\subsection{Conversion of RHB to nanosilica (nanochar)}

The method for the synthesis of nanochar (nanosilica) from rice husks was adopted from the "optimized chemical precipitation-hydrolysis" or sol-gel concept. Briefly, Twenty grams of crushed RHB was refluxed with $2.5 \mathrm{~N} \mathrm{NaOH}$ solution for four hours and then was filtered using Whattman \#41. The residue was washed with $40 \mathrm{~mL}$ of boiling distilled water. The viscous, transparent and colorless solution was allowed to cool down at room temperature and $5 \mathrm{~N} \mathrm{H}_{2} \mathrm{SO}_{4}$ solution was added dropwise to the sodium silicate solution with constant stirring until it reaches a $\mathrm{pH}$ of 9 . The solution was precipitated to gel and was aged for 24 hours at room temperature. After aging, the gel was washed with hot distilled water until the gel turns semi-transparent. The gel was dried in the oven for 48 hours at $80^{\circ} \mathrm{C}$. The dried nanosilica gel was ground to obtain silica nanoparticles $\left(\mathrm{SiO}_{2}\right)$ results

\subsubsection{Characterization of silica nanoparticles}

The synthesized nanosilica was characterized in terms of spectral and structural analysis using Fourier Transform Infrared Spectroscopy (FTIR), surface morphology and diameter size using Scanning Electron Microscopy (SEM)/Elemental Dispersive Spectroscopy (EDS), and particle size analysis using particle Analyzer (Nanopartica).

\section{RESULTS AND DISCUSSION}

\subsection{Uses of CtRHP}

The CtRHP has appropriately designed attachments and, while producing biochar, farmers can use this carbonizer for processing high-value products for generating additional income.

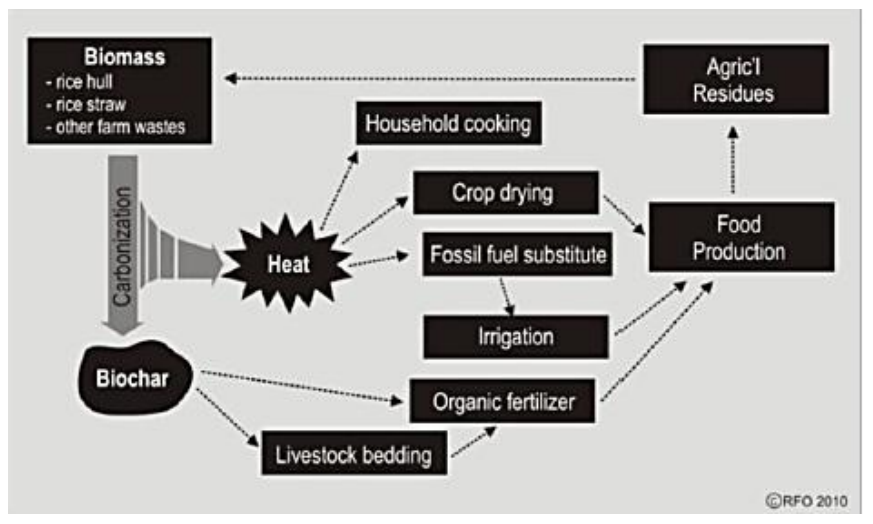

Figure 3. Different uses of CtRHP [9]

A study conducted by Boyles and Orge [13] revealed that the maximum amount of heat energy that can be utilized from CtRH carbonizer is $2.96 \mathrm{~kJ}(49.41 \mathrm{~kW})$ while producing biochar at a rate of $9.6 \mathrm{~kg} / \mathrm{hr}$. Thus, the heat generated from the CtRHP offers a lot of potential benefits in the farm. It can 
be utilized to process food products available on the farm. Additionally, their results of the experiment using the oven test show that drying air temperature distribution inside the drying chamber is uniformly distributed at different tray layers. The highest temperature attained inside the drying chamber is $\sim 250^{\circ} \mathrm{C}$. Furthermore, there is a high temperature difference in different valve settings. Thus, controlling the temperature is possible. Figure 3 shows the possible uses of CtRHP

\subsection{RHB for improving soil fertility}

Shoot, root and total dry matter weight increase linearly as RHB level increases. At $10 \mathrm{~g} \mathrm{RHB} \mathrm{kg}^{-1}$ soil, the difference in total $\mathrm{N}$ concentration of corn was $0.135 \%$ which was significantly higher than plants grown without RHB (Table 2). Highest plant $\mathrm{N}$ concentration was observed in $20 \mathrm{~g} \mathrm{RHB} \mathrm{kg}^{-1}$ soil and these resulted in higher $\mathrm{N}$ uptake. The increase in plant $\mathrm{N}$ was $0.14 \%$ which was a proportionate increase from $10 \mathrm{~g}$ RHB kg-1 soil to $20 \mathrm{~g} \mathrm{RHB} \mathrm{kg}^{-1}$ soil; hence, the plant $\mathrm{N}$ had a significant linear trend. These results were similar to the findings of the paper [14] where addition of biochar consequently improved plant $\mathrm{N}$ concentration in tissue and uptake.

Table 2. Means of plant biomass, and total $\mathrm{N}$ concentration (\%) and uptake $\left(\mathrm{mg} \mathrm{pot}^{-1}\right)$ as affected by Rice Husk Biochar (RHB)

\begin{tabular}{|c|c|c|c|c|c|}
\hline \multirow{2}{*}{$\begin{array}{c}\text { RHB } \\
\text { Levels } \\
\left(\text { g kg }^{-1}\right. \\
\text { soil) }\end{array}$} & \multicolumn{3}{|c|}{$\begin{array}{c}\text { Dry matter } \\
\left(\mathrm{g} \mathrm{pot}^{-1}\right)\end{array}$} & \multicolumn{2}{|c|}{$\mathbf{N}$} \\
\hline & Shoot & Root & Total & $\begin{array}{c}\text { Concentration } \\
(\%)\end{array}$ & $\begin{array}{l}\text { Uptake } \\
\text { (mg pot } \\
\text { 1) }\end{array}$ \\
\hline 0 & $6.14^{\mathrm{c}}$ & $3.33^{\mathrm{c}}$ & $9.47^{\mathrm{c}}$ & $1.33^{\mathrm{c}}$ & $125.20^{\mathrm{c}}$ \\
\hline 10 & $11.72^{b}$ & $5.30^{\mathrm{b}}$ & $17.02^{\mathbf{b}}$ & $1.46^{\mathrm{b}}$ & $249.18^{\mathbf{b}}$ \\
\hline 20 & $13.66^{\mathrm{a}}$ & $6.27^{\mathrm{a}}$ & $19.93^{a}$ & $1.61^{\mathrm{a}}$ & $318.88^{\mathrm{a}}$ \\
\hline $\begin{array}{c}\text { LSD } \\
\text { value }\end{array}$ & 0.83 & 0.63 & 1.44 & 0.04 & 18.99 \\
\hline $\begin{array}{l}\text { Trend } \\
\text { of } \\
\text { Effects }\end{array}$ & Linear & Linear & Linear & Linear & $\begin{array}{l}\text { Linear/ } \\
\text { Quadratic }\end{array}$ \\
\hline
\end{tabular}

Means followed by the same letter within a column are not significantly different at 0.05 probability level.

\subsection{Conversion of biochar into nanosilica}

\subsubsection{Synthesis of nanochar (nanosilica) from RHB}
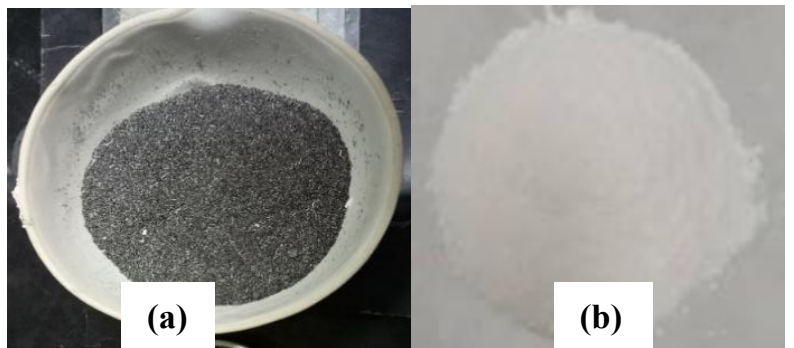

Figure 4. (a) crushed rice RHB and (b) successfully produced nano silica

High-purity nano silica from RHB was successfully synthesized through modified sol-gel method (Figure 4). The sol-gel process is widely used to produce pure silica particles due to its ability to control the particle size, size distribution and morpohology through systemic monitoring of reaction parameters. Other methods like microemulsion, chemical vapour condensation (CVC) and others are costly and difficult to have high degree of purity [18]. Amorphous silica is soluble, and it crucial to retain this amorphous quality to enable a sustainable energy system based on the recycling of the rice husk.

\subsubsection{Characterization of nanosilica}

Nano silica was successfully synthesized (Figure 4). Nano silica occurs in various particle sizes ranging from 5 to $20 \mathrm{~nm}$. The particle size analysis reveals that the silica has a mean average size of $7.8 \mathrm{~nm}$, which was within the required range of nanoparticles size (1-100 nm). At this size level, high surface area and wide distribution of pore sizes is attained. Because of its enhanced properties compared from micro size particles, it had gained wide uses

The morphology of the silica nanoparticles is shown in Figure 5, the SEM image gives a cloudy-like structure which means that the nano silica produced was amorphous. This is due to the aggregation of Si-O-Si and surface $\mathrm{Si}-\mathrm{OH}$ molecular gel network [19]. SEM image also reveals that the particle diameter size of the synthesized silica has values ranging from $31 \mathrm{~nm}$ to $48 \mathrm{~nm}$ which are also within the range of nanoparticle definition (Figure 6).

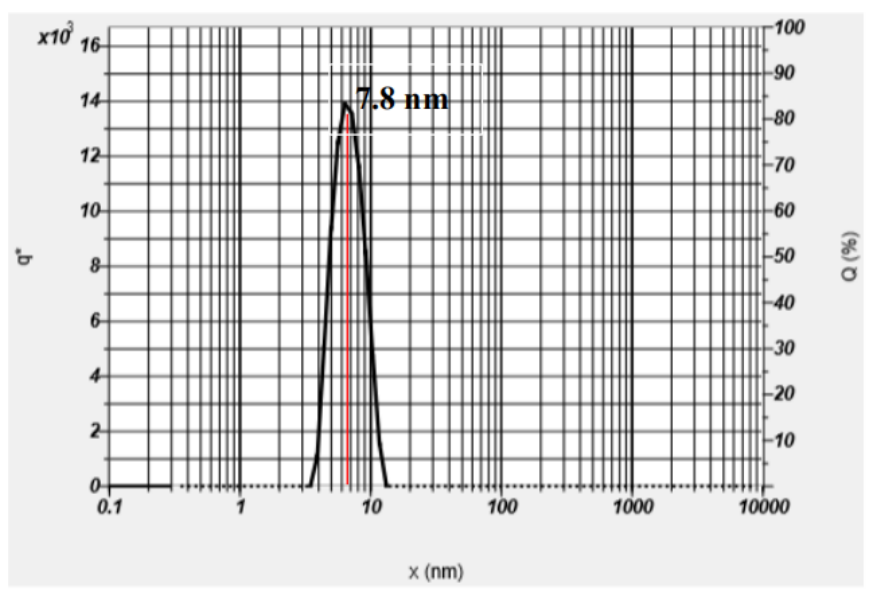

Figure 5. Distribution of particle size of nano silica through Horiba Nanopartica ${ }^{\circledR}$

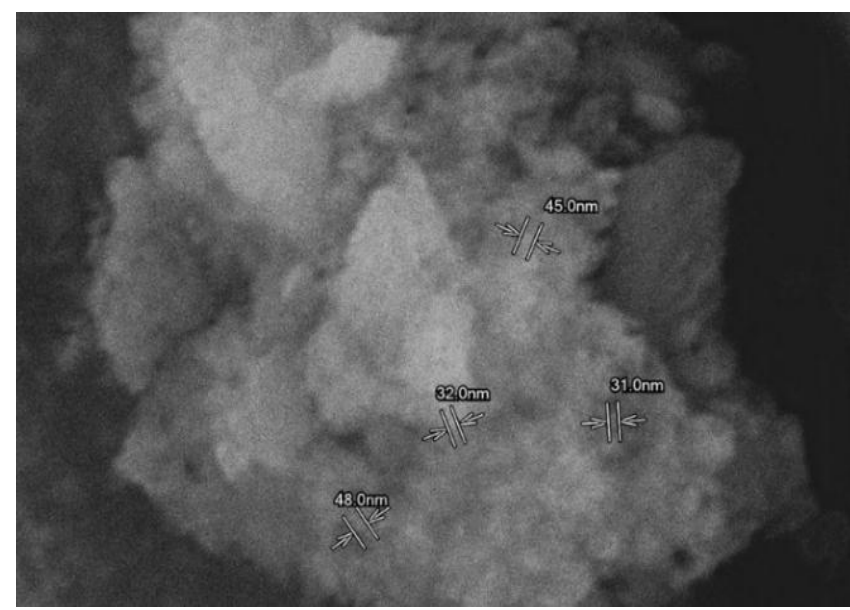

Figure 6. SEM image of the synthesize nano silica $\left(\mathrm{SiO}_{2}\right)$

Strong absorption peaks between 1000 and $1500 \mathrm{~cm}^{-1}$ were observed in the FTIR spectra of silica nanoparticle sample due 
to the stretching vibration peak of $\mathrm{Si}-\mathrm{O}$ bond. The shoulder of $\mathrm{Si}-\mathrm{O}$ peak was due to the presence of the $\mathrm{Si}-\mathrm{O}-\mathrm{Si}$ which had observed vibrational peak between $1000-1500 \mathrm{~cm}^{-1}$. The weak absorption peak of $\mathrm{C}=\mathrm{O}$ stretching was also observed in region ranges from $1500-2000 \mathrm{~cm}^{-1}$ is due to the carbon residue after firing. The strong and broad absorption peak was also observed in the region from $3000 \mathrm{~cm}^{-1}$ to $3600 \mathrm{~cm}^{-1}$ due to the presence of hydroxyl group (O-H stretching). The peak between $2000 \mathrm{~cm}^{-1}-2500 \mathrm{~cm}^{-1}$ was due to the carbon dioxide in the atmosphere (Figure 7). The results suggest that the synthesis of silica nanoparticles is successful due to the presence of the $\mathrm{Si}-\mathrm{O}$ and $\mathrm{OH}$ bonds, however, there are still impurities presence in the sample that cannot be avoided during the experiment. Table 3 shows the summary of the peaks of the functional groups found in the FTIR.

Table 3. Functional groups present in the FTIR of nanosilica

\begin{tabular}{lc}
\hline Vibrational frequency & Functional Group \\
\hline $3000 \mathrm{~cm}^{-1}-4000 \mathrm{~cm}^{-1}$ & Si-OH \\
$2000 \mathrm{~cm}^{-1}-2500 \mathrm{~cm}^{-1}$ & $\mathrm{C}=\mathrm{O}$ Scissoring \\
$1500 \mathrm{~cm}^{-1}-2000 \mathrm{~cm}^{-1}$ & $\mathrm{C}=\mathrm{O}$ Stretching \\
$1000 \mathrm{~cm}^{-1}-1500 \mathrm{~cm}^{-1}$ & Si-O-Si Stretching \\
$800 \mathrm{~cm}^{-1}$ to $1000 \mathrm{~cm}^{-1}$ & Si-C Stretching \\
\hline
\end{tabular}

$\mathrm{X}$-ray diffraction image of the the synthesized nano silica is shown in Figure 8. It is used to deterime the crystallinity of the the nano silica. However, the matrix on the figure shows that the silica is amorphous that confirms the absence of the crystalline structure. Rice husk is amorphous in nature, thus it belongs to non-crystalline silica and non-toxic [20].

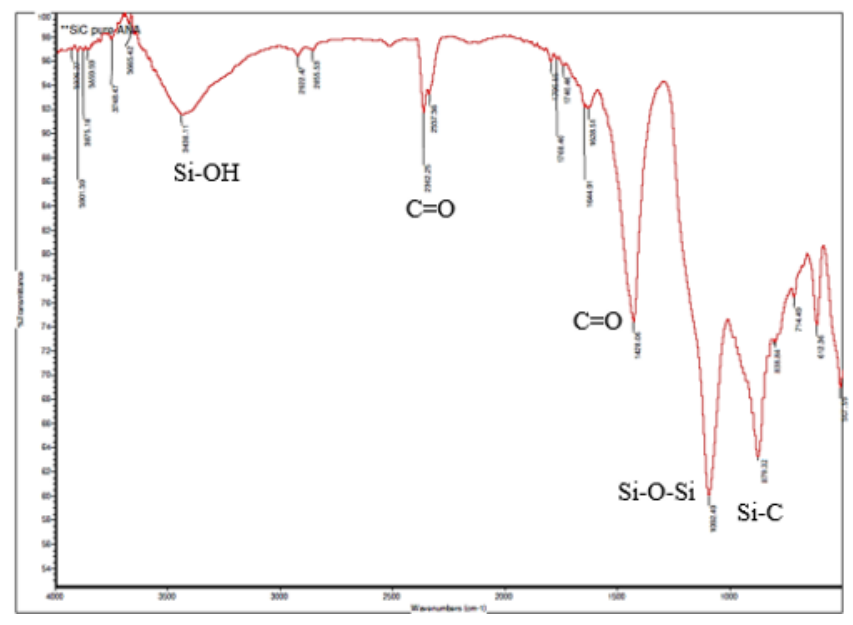

Figure 7. FTIR analysis of nanosilica

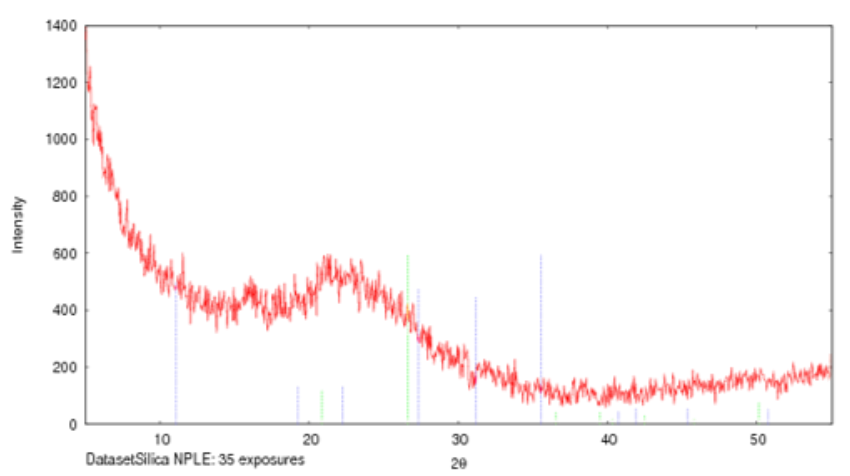

Figure 8. Amorphous structure of nano silica in XRD analysis
Table 4 shows the energy dispersive spectroscopy analysis on nano silica which composed of silica $(\mathrm{Si})$ and oxygen $(\mathrm{O})$. The sample had a $35.37 \%$ of silica and oxygen of $64.63 \%$.

Table 4. EDS analysis of nano silica

\begin{tabular}{cc}
\hline \multirow{2}{*}{ ELEMENT } & Nanosilica \\
\cline { 2 - 2 } & Atomic (\%) \\
\hline $\mathrm{Si}$ & 35.37 \\
$\mathrm{O}$ & 64.63 \\
Total & $100 \%$ \\
\hline
\end{tabular}

\section{CONCLUSIONS}

The CtRHP and its attachments offer a lot of potential in providing opportunities for farmers to be more productive, efficient, and income earner. The cogeneration of biochar and heat would create a more sustainable farming practice since they fit in various activities within the farm. Aside from being a carbon sink (climate change mitigation), biochar helps improve soil condition and fertility which would translate into reduced use of inorganic fertilizers while maintaining higher crop yields and, ultimately, sustained higher income of the farmers. RHB increased $\mathrm{pH}$, organic carbon (OC), and total $\mathrm{N}$ of the soil after harvest. Plant height, biomass, total $\mathrm{N}$ concentration of plant tissue and $\mathrm{N}$ uptake increased linearly with increasing rates of RHB levels. A linear trend of the effects of RHB on soil $\mathrm{pH}, \mathrm{OC}$ and total $\mathrm{N}$ with the increasing rates were observed. Nanosilica was successfully synthesized. Conversion of RHB into nanosilica will have useful beneficial effect in ecology, agriculture and industrial application.

\section{ACKNOWLEDGMENT}

The first part of the study was funded under the OJRCB for Sustainable Agriculture in Developing Countries under the Ministry of Agriculture, Forestry, and Fisheries of Japan coordinated by the United Nations University for Sustainability and Peace (UNU-ISP), Japan. The second part of the study (synthesis and characterization of nanosilica) was partially funded by the Department of Science and Technology-Accelerated Science and Technology Human Resource Program (DOST-ASTRHRDP), Philippines.

\section{REFERENCES}

[1] Tateda, M. (2016). Production and effectiveness of amorphous silica fertilizer from rice husks using a sustainable local energy system. Journal of Scientific Research \& Reports, 9(3): 1-12. https://doi.org/10.9734/jsrr/2016/21825

[2] Sarong, M.M., Orge, R.F. (2015). Effect of rice hull biochar on the fertility and nutrient holding capacity of sandy soils. OIDA International Journal of Sustainable Development, $8(12)$ : 33-44. https://doi.org/10.2495/sdp160271

[3] Umeda, J., Kondoh, K. (2010). High-purification of amorphous silica originated from rice husks by combination of polysaccharide hydrolysis and metallic impurities removal. Industrial Crops and Products, 32(3): 539-544. https://doi.org/10.1016/j.indcrop.2010.07.002 
[4] Lehmann, J., Gaunt, J., Rondon, M. (2006). Biochar sequestration in terrestrial ecosystem - a review. Mitigation and Adaptation Strategies for Global Change, 11: 403-427. https://doi.org/10.1007/s11027-005-9006-5

[5] Chan, K.Y., Xu, Z. (2009). Biochar nutrient properties and their enhancement. In Biochar for Environmental Management: Science and Technology. J. Lehmann, and S. Joseph (eds.) Earthscan Publishers Ltd. 67-84.

[6] Sohi, S.P. (2012). Carbon storage with benefits. Science, 338(6110): 1034-1035 https://doi.org/10.1126/science.1225987

[7] Liu, Y.G., Tan, X.F., Gu, Y.L., Xu, Y., Zeng, G.M., Hu, X.J., Liu, S.B., Wang, X., Liu, S.M., Li, J. (2016). Biochar-based nano-composites for the decontamination of wastewater: A Review. Bioresource Technology, 212: 318-333. https://doi.org/10.1016/j.biortech.2016.04.093

[8] Orge, R.G., Leal, L.V. (2018). Utilizing heat from rice hull biochar production for steam pasteurization of mushroom fruiting bags. Cogent Engineering, 5: 1-12. https://doi.org/10.1080/23311916.2018.1453972

[9] Orge, R.F. (2015). Biochar-based technologies for enhanced productivity, efficiency, resilience \& adaptive capacity of smallholder rice-based farming communities in the Philippines. MARCO Symposium August, 2015 Tsukuba, Japan. 26-28.

[10] Chaudhary, D.S., Jollands, M.C. (2003). Characterization of rice hull ash. Wiley InterScience, 93(1): 1-8. https://doi.org/10.1002/app.20217

[11] Verma, A., Gautam, S.P., Bansal, K.K., Prabhakar, N., Rosenholm, J.M. (2019). Green nanotechnology: Advancement in phytoformulation research. Medicines, 6(39): 1-10. https://doi.org/10.3390/medicines6010039

[12] Lieu, R., Lal, R. (2015). Potentials of engineered nanoparticles as fertilizers for increasing agronomic productions - A review. Science of Total Environment,
514: 131-139.

https://doi.org/10.1016/j.scitotenv.2015.01.104

[13] Boyles, J., Orge, R.F. (2015). Performance of the continuous-type rice hull carbonizer as heat source in food product processing. OIDA International Journal of Sustainable Development, 8(11): 25-34. https://ssrn.com/abstract=2709112

[14] PCARR. (1980). Standard Methods of Analysis for Soil Plant Tissue, Water and Fertilizer. Los Baños, Laguna.

[15] Thomas, G.W. (1982). Exchangeable cations (potassium chloride method). In: A. L. Page, R. H. Miller and D.R. Keeney (eds). Methods of soil analysis: Part 2. Chemical and Microbiological Properties. Agron. Monogr. 9. (2nd ed). ASA and SSSA, Madison, WI. 159-165.

[16] Olsen, S.R., Sommers, L.E. (1982). Phosphorus. In: A.L. Page, R.H. Miller and D.R. Keeney (eds). Methods of Soil Analysis: Part 2. Chemical and Microbial Properties. Agron.Monogr.9. (2nd ed). ASA and SSSA, Madison, WI. 402-430.

[17] ISRIC. (1995). Procedure for Soil Analysis (L. P. Van Reuwijk, Editor). Wageningen, Netherlands, pp. 106.

[18] Tagoe, S.O., Horiuchi, T., Matsui, T. (2008). Preliminary evaluation of the effects of carbonized chicken manure, refuse derived fuel and $\mathrm{K}$ fertilizer application on the growth, nodulation, yield, $\mathrm{N}$ and $\mathrm{P}$ contents of soybean and cowpea in the greenhouse. Afri. J. Agric. Res., 3(11): 759-774.

[19] Hench, L.L., West, J.K. (2004). The Sol-Gel process. Chemical Reviews, 90(1): 12142-12153. https://doi.org/10.1021/cr00099a003

[20] Real, C., Alcala, M.D., Criado, J.M. (1996). Preparation of silica from rice husks. Journal of the American Ceramic Society, 79(8): 2012-2020. https://doi.org/10.1111/j.1151-2916.1996.tb08931.x 